\title{
CESPUC
}

\section{O NOVO REALISMO EM LUANDINO VIEIRA E YINKA SHONIBARE}

\author{
Wellington Marçal de Carvalho*
}

\begin{abstract}
Resumo
Neste trabalho pretende-se refletir sobre o novo realismo que emerge da criação literária do angolano José Luandino Vieira e do construto artístico do anglo-nigeriano Yinka Shonibare, MBE. A tônica será na direção de considerar o corpus com base em algumas feições de realismo. O viés analítico empreendido propõe-se a evidenciar as tentativas de Luandino de encenar questões decorrentes de processos de misturas que caracterizam momentos históricos de Angola e Luanda, marcados pelas mesclagem de tradições. No mesmo viés, discutemse as estratégias que contribuem para desmascarar a falácia acerca da autenticidade étnica, expressas na arte de Shonibare.
\end{abstract}

Palavras-chave: Literatura angolana; Arte anglo-nigeriana; Realismo; Literatura e neorealismo; Arte e neorealismo.

\section{THE NEW REALISM ON LUANDINO VIEIRA AND YINKA SHONIBARE}

\section{Abstract}

This current work aims to reflect on the new realism that emerges from the literary creation of Angolan José Luandino Vieira and the artistic construct from Anglo-NigerianYinka Shonibare, MBE. Tonic Will be towards considering the corpus by analyzing some realism features. The analytical bias was intended to highlight Luandino'sattempts to stage issues arising from mixture processes that characterize historical moments in Angola and Luanda, marked by merge of traditions. On the same trend, strategies that contribute to unmasking the fallacy about ethnic authenticity, expressed in the art of Shonibare, are discussed.

Keywords: Angolan fiction; Anglo-Nigerian art; Realism; Literature and neorealism; Art and neorealism.

Recebido em 24/01/2018 Aceito em: 12/02/2018

* Doutor em Letras - Literaturas de língua portuguesa, pela PUC Minas (bolsista CAPES), docente do Departamento de Ciência da Informação - Biblioteconomia da Universidade Federal de Rondônia. 


\section{Introdução}

"Escrevi 'Ualalapi' com o sentido de oferecer outra história que não a oficial...”

(KHOSA, 2013, p. 2)

Recentemente, por ocasião do lançamento do romance Ualalapi ${ }^{1}$, o escritor moçambicano Ungulani Ba Ka Khosa tecia instigantes considerações sobre o espírito que o movera a escrever aquela obra. Em uma delas Khosa afirmava a intenção de apresentar ao povo de seu país uma abordagem sobre Ngungunhane, o imperador das terras de Gaza, diferente da versão oficialmente veiculada pelo colonizador português. O resultado é um brilhante exercício de trazer à superfície uma história que forçosamente havia sido soterrada, por interesses escusos, mas que, ao ser ressignificada pela escrita literária, sinalizava o núcleo duro do real como performador de um texto insurgente que pode ser lido com matizes de proposta de um novo realismo.

Com essa motivação, o presente trabalho pretende refletir sobre elementos de um novo realismo que emerge da criação literária do escritor angolano José Luandino Vieira, especificamente no conto, escrito em 1972, "Estória de família (Dona Antónia de Sousa Neto)" e do construto artístico do anglo-nigeriano Yinka Shonibare, BEM, na instalação, de 2009, Party time: re-imagine America e na escultura, de 2013, Last supper (after Leonardo). A hipótese é que assim como em Ualalapi, o trabalho de Luandino Vieira e de Yinka Shonibare, em alguma medida, encena questões decorrentes de processos de misturas que caracterizam momentos históricos de Angola e Luanda e, também, opera mesclagens de tradições, que contribuem para desmascarar a falácia acerca da autenticidade étnica, expressas na arte de Shonibare.

A tônica será considerar o corpus analisado segundo algumas feições de realismo discutidas, principalmente, por Schøllhammer. Esse pesquisador propõe, em importante artigo denominado "Realismo afetivo: evocar o realismo além da representação", publicado em 2012, um entendimento do conceito de "realismo" que o presente trabalho retoma:

Minha sugestão para a discussão atual é entender o Realismo hoje como uma estranha combinação entre representação e não representação, por um lado, visível na retomada de uma herança de diferentes formas históricas e, por outro, na atenção em relação à literatura em sua capacidade de intervir na realidade receptiva e de agenciar experiências perceptivas, afetivas e performáticas que se tornam reais. (SCHØLLHAMMER, 2012, p. 129-130).

A sugestão inicial de Schøllhammer pode ser interessante para nortear uma leitura dos trabalhos de Luandino e Yinka, os quais operam uma intervenção na realidade receptiva e, ao mesmo tempo, articulam vivências nos campos da percepção, dos afetos e das performances e, assim, o leitor/espectador pode se ver embaraçado no confronto com a realidade que reverbera da ativação do poder estético de suas obras, que coloca esse mesmo sujeito em questão. É como se as criações que serão aqui analisadas se configurassem como uma possibilidade de

1 Faz-se referência à estada de Ungulani Ba Ka Khosa promovida pelo Centro de Estudos Africanos da Universidade Federal de Minas Gerais, em parceria com a Editora Nandyala, em agosto de 2013, para lançamento do romance Ualalapi, pela mencionada Editora. Na ocasião também esteve presente a escritora caboverdiana Vera Duarte. 
experiência performática, nos termos de Schøllhammer (2012, p. 145), uma vez que o conjunto, por elas formado, almeja "a potência afetiva de um evento e envolve o sujeito sensivelmente no desdobramento de sua realização de mundo."

\section{O trabalho sujo de Luandino Vieira e Yinka Shonibare}

Tecidas as considerações preliminares propõe-se a entrada no corpus eleito. Será analisado, em primeiro lugar, um conto escrito por Luandino e, logo após, dois trabalhos de Shonibare. A obra intitulada Lourentinho, Dona Antônia de Sousa Neto \& Eu foi publicada pela primeira vez em 1981, muito embora os dois contos que a constituem tenham sido escritos, respectivamente, em 28/06/1971 e 06/07/1971 - "Kinaxixi Kiami (Lourentinho)" e "Estória de família (Dona Antónia de Sousa Neto)”, elaborados entre os dias 08 a 15/05/1972. Assim como grande parte da obra de Luandino, esse volume também nasceu enquanto o autor esteve preso no Campo de Concentração do Tarrafal, em Cabo Verde. ${ }^{2}$

Nesse livro, o trabalho de tensionamento da língua portuguesa operacionalizado pelo escritor parece ter sido radicalizado, se comparado a outras de suas obras publicadas anteriormente. Se observado o percurso trilhado por Luandino em seus textos curtos, como os contos e novelas, é perceptível a aquisição da destreza, crescente, em lidar com a língua portuguesa em toda a sua plasticidade para acolher elementos das culturas e dos falares locais, amalgamando-os no seio do idioma lusófono. Com base nisso, o escritor apresenta uma língua sempre nova e, porque não dizer, exigente em argúcia e permanente estado de alerta para o que o texto diz em suas entrelinhas e não ditos e, fundamentalmente, na aparente roupagem de inocência em que está travestido.

Não pode ser desprezada a ausência de um glossário na composição do livro, como o leitor já havia se acostumado, uma vez que, em quase todas as demais obras de Luandino, esse dispositivo auxiliar de leitura possuía lugar certo. Encontravam-se glossários acompanhando o texto do romance João Vêncio: os seus amores (1979), ou, no volume de contos A cidade e a infância (1957), além de em vários outros títulos.

Ainda que a discussão sobre o motivo desse hiato não tenha lugar aqui, um conhecimento exíguo do percurso literário de Luandino permite considerar que, no caso da obra em apreço, o texto puro, sem a ferramenta auxiliar, pode significar que o leitor, assim como o criador da obra, é convidado a mergulhar na experiência estética que balizou a gestação desses dois contos. Aceito o convite, o leitor poderá degustar, por exemplo, em "Kinaxixi Kiami (Lourentinho)", uma magnífica aula sobre a flora local, que tangencia o desenrolar da narrativa, intensamente recheada com termos pouco afeitos aos falantes do português padrão.

Ciente de ter sido bem injusto com a obra de Luandino nas breves linhas anteriores, vale registrar a abertura que o conto "Estória de família (Dona Antónia de Sousa Neto)", que narra o "estórico" e "mangonhento sábado de comes-e-bebes", "o almoço esse que era de-pedido, virou lição etnograstrológica para brasileiro ver” (VIEIRA, 2004, p. 57), na medida em que

2 Para maiores informações sobre a peculiaridade a respeito do lugar de gestação da obra de Luandino Vieira, sugere-se o exame do Quadro cronológico da obra de Luandino Vieira, organizado por Michel Laban (1980, p. 312). 
torna plausível certa aproximação com a instalação Party time: re-imagine America, de Yinka Shonibare, MBE, como mais adiante se demonstrará.

Além disso, parece sobressair, na presente sugestão de leitura dialógica de parte da obra desses dois africanos, um exemplo do que o filósofo esloveno Slavoj Zizek denomina de padrão de paralaxe. Tal fato consolida uma razoável comunicação de seus construtos artísticos e literários. Esse padrão de paralaxe é, de acordo com Zizek (2008, p. 32), "o deslocamento aparente de um objeto (mudança de sua posição em relação ao fundo) causado pela mudança do ponto de observação que permite nova linha de visão". É como se as representações encenadas naquelas obras instigassem o rompimento da "anestesia cultural" aludida por Schøllhammer (2012, p. 136), uma vez que obrigam o deslocamento do objeto, conforme postulado por Zizek (2008, p. 32) e, assim, oferecessem outra linha de visão, em paralaxe, que deixa evidente processos de misturas e mesclas de tradições, além das conflituosas interações do binômio colonizado e seu algoz colonizador.

O conto de Luandino Vieira narra um estupendo almoço oferecido por ocasião de um pedido de casamento. Isso é apenas um subterfúgio para a narrativa pontuar, em diferentes matizes, o lugar marginal que parte daquela sociedade, representada pelos convivas dispostos em redor das mesas, reserva à tradição, particularmente encarnada, por exemplo, na personagem da velha nga Tonha dia Kaj'vintém. O ardil do narrador de se valer do matiz irônico para tecer a enunciação também foi problematizado por Fonseca (2016, p. 19), principalmente na marcação firme que a velha senhora irá desempenha para o desenrolar da trama:

Desde o início da narrativa, configura-se o tom irônico do narrador, bem como a intenção do texto de mergulhar em costumes e na tradição angolana de festas, já alterados pelos "ventos históricos" e por demandas de uma ordem que abriga as ordens sociais várias que o conto explora. Uma delas seria o fato de a língua quimbunda ser deslocada para o lugar para onde ficará Donta Antónia de Sousa, a velha bessangana que, aparentemente desterrada dos acontecimentos que se dão na casa, deles participa, valendo-se de gritos e das "palavras podres" que as boas maneiras do anfitrião se esforçavam por amenizar. (FONSECA, 2016, p. 19)

Essa aparente indiferença em relação à "velha bessangana no exílio de sombra mandioqueira" (VIEIRA, 2004, p. 57), ilustrado na cena do banquete, se transformaria em "estóica data a fixar" (VIEIRA, 2004, p. 57).

A velha é nga Tonha dia Kaj'vintém - perdão!: senhora-dona Antónia de Sousa, vocência sem favor. Vem dos tempos do antigamente, lá onde a bela quindumba e os panos traçados fazem o sol na massemba... Só que, nesta hora, desterrada da história, deixa embranquecer os cabelos e sonha à sombra murcha dos anos. (VIEIRA, 2004, p. 57).

Fortemente irônico, o narrador registra a posição de desterro da história para onde foi empurrada nga Tonha e, ao mesmo tempo, informa que, naquela reunião, sobressairia "a tradição - que de tradição que ia ser todo o almoço, promovido de curial festejo de pedido a ponto d'honra: jornalista brasilenho, com sua esposa, era o escolhido de tanta gente chamada" (VIEIRA, 2004, p. 58). De sua posição de desterrada, Nga Tonha irá demarcar a sua presença 
com lancinantes golpes de cachimbo, sempre incômoda para os convivas, sempre inconveniente para os familiares. Da sombra da mandioqueira, à revelia de todos, imporá seu jogo que consiste em reprovar tudo o que diz respeito ao banquete. Ademais, como uma representante das bessanganas de Angola, a velha senhora de classe social acostumada a grandes e requintados banquetes impunha, nos tempos mesclados pela "fraqueza de ventos históricos" (VIEIRA, 2004, p. 57) a força de sua existência. Até mesmo ditava o que deveria compor o cardápio do dia, importunando a responsável pela cozinha nga Mabunda, que não pode deixar de levá-la em consideração: "que o almoço devia de seguir a linha do simples, não funguissar. "Kiakudikila, kiazanga..." - sabedorias" (VIEIRA, 2004, p. 59). Uma verdadeira "rompe-grupo" (VIEIRA, 2004, p. 58), e quando abria a boca era para decretar seu veto: "Que não e nunca; funguissada assim chama azar; com os-da-família, calundus e ilundos e miondonas, se já se viu... E baforada final: mesmo que o tal brasileiro era mulato, o poeta era branco, e branco sempre traz branco igual, ponto final sem reticências" (VIEIRA, 2004, p. 58):

E mais não disse - se exilou sob a mandioqueira, sua voz só de berrar fogo-fogo; cuspir, sonhar e espiar as coisas que chegavam; xingar as pessoas, deixar embranquecer os anos vividos. [...] Nada que sucedeu, passado é caixão vazio, nem morto mais mora - senhora dona Antónia esperou hora de zombar os convivas. (VIEIRA, 2004, p. 58).

Vencida a definição do cardápio a ser resolvido, mesmo a partir da sombra da mandioqueira, a velha nga Tonha agora despenderá sua energia no recebimento, torto, dos convivas. A começar pela indelicadeza dos primeiros que chegam, como que avisados, na mesma hora em que ficam prontos "os panelões [a] saírem do fogo das massuícas" (VIEIRA, 2004, p. 61). "Primeiro: pulga e dedo-pulgar - xingo atento de nga Antónia, vigilando regabofe de convidados. Nos seus tempos, nem para cumprimentos, quanto mais..." (VIEIRA, 2004, p. 61).

Como para a velha bessangana tudo aquilo era um despropósito, para dois dos convidados em especial ela exercerá, acidamente, o seu descontento tão logo os vê adentrar os portões da residência. O primeiro é um ex-advogado de sanzala, um "Descomportado cívico..."(VIEIRA, 2004, p. 61) e o outro é o jornalista angolano Cunha. Nem bem assomam à porta, ela dispara em bom quimbundo só dela:

"Zita, Zit'ééé!... Ngi-bekele kala dia tubia!..." - don'Antonha, berrenta, de lhes ver donos no
avançar pelo quintal. Tudo cala; se ouve estrelejar da lenha ardendo; e o número dois suspende
menequenos, fareja assunto-de-crónica. "É mamã Tonha! Hoje não se lhe pode falar... É a
idade, Temisto!..." - diz o dono da casa e Temístocles Zé da Cunha sorri, sua desconfiança
ida. (VIEIRA, 2004, p. 61).

Ao constatar que ainda não eram os convidados de honra, desiludida, a "senhora-dona Antónia fecha os olhos, morde o cachimbo de barro" (VIEIRA, 2004, p. 61), não sem antes soltar seu grito de guerra: "Abixila, abixila kiá!..." (VIEIRA, 2004, p. 61). Passado algum tempo, a casa já repleta de gente, correria da meninada pelo quintal, trançar de panelas fumegantes da cozinha para a mesa no terreiro, Temístocles a reger toda aquela confusão e, enquanto isso, a velha lá na sombra, jogada, mas imponente, esbravejando ao léu: "“Ngi-bekele kala dia tubia!" - ninguém lhe ouve, dona Antónia berra. Tudo só já corridas, pratos e panelas; travessas, risos; ralhos dos mais-velhos. Na sua mesa os menores já batem garfos e facas” (VIEIRA, 2004, p. 62). 
"E dona Antónia de Sousa desiste; cospe e xinga - no fundo, ri. [...] A mandioqueira é doce xaxualho antigo, verde amiga. "O mindele, ku fésa?!..." - resmunga. E depois: "Kala dia túbia!" - berra"” (VIEIRA, 2004, p. 62). Não sendo o bastante para constranger o desenrolar do almoço, com seus gritos, sua "rouca estrídula voz de ontens" (VIEIRA, 2004, p. 63), nga Tonha marotamente recebe o frescor da brisa sob o mandiocal e vai acompanhando a invasão da gente faminta e, mesmo quando berrava ou urrava seus impropérios, não era percebida senão muito esporadicamente por seu filho Temístocles.

Porém, com a sapiência que a maturidade lhe confere, do seu canto ela sorri, velhaca: "Espera como quem ressuscita e sabe de certa ciência o futuro" (VIEIRA, 2004, p. 63). E isso a permitirá, insolentemente, atitudes pouco ortodoxas para o momento de uma refeição, ainda mais quando em uma coletividade, como se vê no ato a seguir: "E a senhora dona Antónia de Sousa - digo: nga Tonha dia Kaj'vintém, retiro o vocência - sem quê nem mais respeito, peida-se inocentemente e vai fumando o seu cachimbo de barro à sombra da mandioqueira do passado" (VIEIRA, 2004, p. 64, grifo nosso). E cai no sono.

Nga Tonha só desperta com a barulhada das "palmas e bravos, bater de garfos, muitos-bens todos atroando o ar" (VIEIRA, 2004, p. 65), dirigidos ao Temístocles que resolvera congratular seus convidados antes de servir a refeição. E "don'Antónia, que ninguém não vê, perdida em sonhos vindicatórios para lá da sebe de buganvílias, no gueto de mandioqueira. "Tubia!" - ainda berra, mas quem que ouve necessidades primitivescas em hora de musas inspiradas?" (VIEIRA, 2004, p. 65). É interessante verificar uma das vezes em que o narrador pontua o descaso para com a velha senhora, como o excerto adiante demonstra:

\begin{abstract}
A bem da verdade, não arderam troias - mas a ovação não é que ia sendo derrota diplomática de dona Antónia, teimante resistente pacífica? Pois que em seu caduco passo até fez furo em sebe de buganvília, espionagens orgulhosas. Mas só viu às e alegrias, gritos, palmas e gargalhadas no ar que o tambarineiro azulava - corriam as ajudantas com travessas e panelas, as mesas burburinhavam de guardanapos abertos, pombas à boa paz das armas nas mãos: garfos, colheres, facas e as montanhas de frutas pelas quindas, pelas mesas. (VIEIRA, 2004, p. 66).
\end{abstract}

Eis que o orador motivado, talvez, pela positiva recepção de sua fala inicial "ganha, de repente, a intuição do lugar da natureza no coração das palavras: deixa perpassar o verbo de silenciado xaxualho do tambarineiro, pausa verde, refrescadora de emoções. Para, num golpe de is, fazer rumo ao fim" (VIEIRA, 2004, p. 71):

"Embora tidos e havidos de retrógrados por espíritos facciosos que por aí pululam sem norte, malfadadamente, nós, que à paixão e inteligência das coisas tradicionais deste impoluto ancião que se chama Damasceno Sousa Neto não teceremos elogios suficientes - e permita-se-me evocar, em preito de saudade, outros saudosos insignes de nossas batalhas em prol de nosso folclore desde os saudosos tempos dos "Cidralinos" onde pontificaram espíritos musicais da estirpe de um José Kabangula, dum Manzuá, dum Xico-Vaidoso e, modéstia à parte, de nós próprios o Calenhitaco..." (VIEIRA, 2004, p. 71, grifos nossos). 
Obviamente a propalada paixão e inteligência das coisas tradicionais e as decantadas batalhas em prol do folclore, soberbamente golpeadas pela verve de Temístocles colidem na recepção despeitada de dona Antónia, que do seu mandiocal berra: "Kala dia tubia, ndumbu de merda!..." (VIEIRA, 2004, p. 77). Convém analisar com mais vagar tanta eloquência e tão calorosa ovação à apaixonada falação de Temístocles. Na verdade, ela parece desvirtuar o tratamento realmente conferido pelo dono da casa e compartilhado por seus convivas, quanto ao que insiste ser um baluarte do folclore e das coisas tradicionais. $\mathrm{O}$ alerta feito pelo narrador quando pontua que o "vento do tempo vai levantar saia da verdade" (VIEIRA, 2004, p. 77) indicia a parcela de cautela para que o leitor não se deixe ludibriar pelo verborrágico Temístocles. Mais prudente é aceitar o conselho do narrador quanto a dar tempo ao tempo para as coisas melhor se esclarecerem, pois "o que sempre não precisa é impaciência de namoradão..." (VIEIRA, 2004, p. 77).

A velha jogada para debaixo da sombra do mandiocal, que até para ser alimentada foi, por acaso, a última, e que tem como companheira apenas o "silenciado xaxualho do tambarineiro" (VIEIRA, 2004, p. 71), registra, com a força de sua presença, a sobrevivência da tradição que persiste, solidamente, na figura renitente de nga Tonha:

Cairia o pano, se em teatro. Na vida só cai a tarde e cai o tempo, caem as milionésimas folhas de nosso tambarineiro estórico e o musicado silêncio, para que dona Antónia de Sousa - nga Tonha dia Ukamba Uámi, minha e nossa senhora do antigamente - adormeça, virginal, em sua prisão de ar e velhos sonhos. (VIEIRA, 2004, p. 85).

Cumpre destacar a assertividade da estratégia do escritor angolano que deixa transparecer as complicações advindas do inevitável convívio de temporalidades diferentes. Outra coisa não é, por exemplo, o que atesta a presença de "mamã Tonha" (VIEIRA, 2004, p. 61) e os demais convivas do almoço. De certa maneira, esse vitral de personagens tão variados parece alegorizar a própria contemporaneidade do chão luandense, ou, mesmo, do chão angolano. $\mathrm{O}$ olhar atento de Luandino Vieira já alertava para a necessária imbricação de perspectivas para a manutenção do cotidiano em Angola e, de algum modo, o almoço festivo performatizaria essa constatação.

É plausível considerar que a personagem nga Tonha dia Ukamba Uámi, a velha bessangana, é bastante emblemática na imposição de sua presença naquele tecido social erigido em tantas misturas e, como já dito, em diferentes temporalidades angolanas, fato que traz à superfície a beleza da narrativa que abraça essas mesclas no corpo da cena enunciativa. Parece consolidarse, na estratégia de Luandino no conto em discussão, traços do realismo afetivo que opta por colocar em primeiro plano o que justamente poderia ser arbitrado como supérfluo:

Na prosa contemporânea o impacto afetivo não surge em decorrência do supérfluo dentro da descrição representativa, senão em consequência de uma redução radical do descritivo, de uma subtração na estrutura narrativa da construção sintática de ação e da preeminência da oralidade contundente do discurso em procura do impacto cruel da palavra-corpo. (SCHØLLHAMMER, 2012, p. 139). 


\section{CESPUC \\ 1 O SEMESTRE DE $2018-$ N. 32}

\section{Welumgton marsal de (arvalho}

Segundo o crítico literário brasileiro Antonio Candido:

O realismo se baseia nalguns pressupostos, inclusive o tratamento privilegiado dos pormenores, pelo seu acúmulo ou pela sua contextualização adequada. [...] A visão realista pressupõe (1) a multiplicação do pormenor, (2) a sua especificação progressiva e (3) o registro de suas alterações no tempo. (CANDIDO, 1993, p. 123).

Ainda para Candido (1993, p. 124) "a visão realista só se completa graças ao registro das alterações trazidas ao pormenor pelo tempo, que pode ir de algumas horas até um século - e ao introduzir a duração introduz a história no cerne da representação da realidade." As considerações de Fonseca (2016, p. 20) poderiam reforçar a linha discursiva do presente trabalho, uma vez que a pesquisadora acentua a multiplicidade de elementos que nutrem a formação do chão luandense:

Ao se fazer cenário de tempos marcados por prisões e desassossegos, o conto permite que as misturas, no nível dos enunciados e da diegese, figurem como construções linguageiras que atravessam o léxico, a sintaxe e a semântica da língua imposta pela administração de que faz parte Damasceno, como antigo chefe-de-posto e também "a senhora dona Antónia de Sousa - digo: nga Tonha dia Kaj'vintém." (VIEIRA, 1991, p. 84), personagem de um cenário que o narrador registra com a intenção de assinalar os modos como a "vermelha poeira mussequíssima" (VIEIRA, 1991, p. 83) infiltra-se na festa, de apreender os detalhes de uma festa que congrega falares, tradições e misturas muito próprias da cidade de Luanda, em determinado período da colonização portuguesa. (FONSECA, 2016, p. 20).

Se no texto de Luandino, como até aqui foi trabalhado, efetiva-se um projeto de tentativa de problematização da reconfiguração das tradições no seio daquela sociedade, sobretudo pelo papel encarnado por nga Tonha dia Kaj'vintém, observa-se, por conseguinte, a estetização de outras feições de realismo presentificadas no programa artistítico do anglo-nigeriano Yinka Shonibare. É dele que, doravante, ocupar-se-á o presente trabalho. Como ponto de aproximação detonador das reflexões aqui objetivadas, ressalta-se a cena de convivas reunidos à mesa para a refeição, magnificamente registrada tanto em Luandino quanto em Yinka.

O artista anglo-nigeriano Yinka Shonibare, MBE, é radicado em Lagos, na Nigéria, desde os três anos de idade. Na juventude retorna para Londres para estudar Belas Artes no Byam Shaw College of Art e, posteriormente, gradua-se no Goldsmiths College, integrando-se à geração dos Young British Artists. Atualmente vive e trabalha em East End, Londres. Em termos biográficos pode-se sublinhar ainda que,

durante a última década, [Yinka] se tornou bem conhecido por sua exploração do colonialismo e pós-colonialismo dentro do contexto contemporâneo de globalização. O trabalho de Shonibare explora esses temas, em paralelo com temas como raça e classe, por meio de pinturas, esculturas, fotografias e, mais recentemente, filmes e performances. Usando esse amplo espectro, Shonibare examina em particular a construção da identidade e a emaranhada inter-relação entre África e Europa e suas respectivas histórias econômica e política. Mesclando história da arte ocidental e literatura, ele questiona o que hoje constitui nossa identidade coletiva contemporânea. Descreve-se como um 'pós-colonial' híbrido e indaga sobre os sentidos de cultura e nação. Em 2004 foi indicado para o prêmio Turner e foi condecorado 


\section{（ESPUC \\ 1 O SEMESTRE DE $2018-$ N. 32}

Membro da "Mais Excelente Ordem do Império Britânico", adicionando esse título ao seu nome profissional. (YINKA, 2013).

Sobre a espécie de 'prótese' apensa ao nome de trabalho do artista, a crítica de arte Coline Milliard (2009) ressalta que Shonibare considera as iniciais "MBE" como uma espécie de 'cavalo de Tróia' e que uma abordagem dessa ordem surte um efeito interessante, uma vez que passa a permiti-lo fazer parte e questionar determinados espaços, já que compor a 'tendência dominante' também cria interessantes ambivalências. Em depoimento colhido por Charles Giuliano, o artista relata sobre sua peculiar estratégia:

De alguma forma, quando as pessoas vêem um artista de origem africana, pensam: "Oh, está aqui para protestar", o artista é citado no catálogo. "Sim, tudo bem, estou aqui para protestar, mas eu farei isto como um cavalheiro. Isto irá soar muito bem. Você nem sempre irá perceber que estou protestando, você irá convidar-me para seu museu porque o trabalho é bom, e quando eu estiver lá dentro já será muito tarde. Mas eu tenho que fazer isto gentilmente porque se eu já vir até você com uma faca, você irá mandar-me de volta. (GIULIANO, 2004).

Entendida essa máscara sincera como um estratagema, têm-se que as criações deste artista anglo-nigeriano podem ser analisadas como esforço de retomada dos vários conflitos africanos e/ou em África, questionados firmemente a cada novo trabalho. É notável sua mundividência quanto à aventada pureza dos grupos étnicos, para o qual "a autenticidade étnica é uma falácia e uma posição social parece ser de relevância apenas na esfera material”. (BARAN, 2010).

Ao passo em que suas obras foram se gestando, algumas recorrências tornaram possível o reconhecimento de uma "dicção shonibariana", singularizando-o do conjunto de outros artistas. Como principais indícios de seu fazer, ressaltam-se quatro elementos: a) os manequins em tamanho natural; b) a decaptação desses mesmos manequins; c) o traje à moda do final da era vitoriana; e d) os tecidos, com estamparia em batique, pseudo-africanos.

O panejamento, considerado por Yinka como uma "metáfora do multiculturalismo" (COOKE, 2010), tornou-se uma das marcas registradas de seu trabalho. ${ }^{3} \mathrm{O}$ fato de os manequins estarem vestidos com tecidos de estamparia africana aparentemente já demonstra uma crítica ao colonialismo. De acordo com a pesquisadora brasileira Thais Flores Diniz, Shonibare,

usando tecidos pseudo-africanos, manequins acéfalos e muito humor, [...] desconstrói os estereótipos sobre raça, classe e cultura. [...] Aos olhos do espectador, os tecidos são de origem africana. Porém, em cada traje, fica patente a ambiguidade, pois os tecidos que Shonibare compra como africanos são cópias de estampados holandeses manufaturados nas fábricas inglesas por meio de uma técnica indonésia. No século 19, eles eram exportados para a África e se tornaram populares na Costa do Ouro; por isso hoje são vistos como originários dali. As estampas são portanto exaltadas (consideradas africanas) mas, ao mesmo tempo, modificadas (falsas), o que sugere um tom de subversão. Em relação a isto, diz Shonibare: "É importante que eu não vá a África para comprá-los (os tecidos) pois assim todas as implicações de exotismo da África se mostram falsas". (DINIZ, 2011, p. 362).

3 Para mais informações sobre o tecido batique usado por Yinka ver, por exemplo, os trabalhos de Carvalho (2011); Cooke, (2010); Milliard (2009); Olowu (2009); Wyndham (2008). Cumpre destacar a interessante entrevista de Shonibare concedida a Okwui Enwezar (2003), em que o artista registra que o pesquisador Kobena Mercer foi o primeiro a perceber a sua intenção com o uso do tecido batique. 
Assim como Luandino Vieira no campo da literatura, Shonibare recicla os dados da história e da realidade, ressignificando-os em suas obras. Os manequins degolados rasuram o processo de dominação da África. Yinka considera a ausência de cabeça dos manequins como um jogo "intrinsecamente violento, porém nunca de forma gráfica" (SONTAG, 2009). Não há jorro de sangue, mas a sugestão está lá presente.

É razoável considerar que a obra de Shonibare, sobretudo a instalação e a escultura que nutrem a presente discussão, veiculam "imagens de violência" ainda que seu fazer artístico emoldure testemunhos poéticos, permitindo o descortinar de novas realidades, algo que talvez pudesse ser melhor compreendido à luz do que Schøllhammer (2012, p. 145) problematizava acerca do realismo afetivo, que abraçaria "as experiências performáticas que procuram na obra a potência afetiva de um evento e envolve o sujeito sensivelmente no desdobramento de sua realização no mundo". O próprio artista registra que:

\footnotetext{
"Nos últimos anos, tenho estado incrivelmente incomodado pela guinada no volume de notícias sobre guerras e assassinatos e massacres e mortes" ele diz. "Vi-me confrontando algumas questões embaraçosas. Eu poderia continuar a criar em tal ambiência? Eu poderia ignorar o trauma ou dar a ele forma em meu trabalho? Eu conclui, cada vez mais tranqüilo, que não poderia ignorar tudo isso." (CAMPBELL-JOHNSTON, 2006).
}

Convém lembrar a hipótese apresentada por Alexandre Montaury, ao analisar a escrita testemunhal do angolano Antônio Jacinto, notadamente em sua intenção imagética:

\begin{abstract}
Uma escrita testemunhal [seria aquela] presa à experiência empírica do autor e articulada a um desejo de pôr em circulação imagens da violência que fizeram parte do contexto das guerras coloniais e também das tensões internas que assolaram diversos segmentos da sociedade angolana. (MONTAURY, 2012, p. 106).
\end{abstract}

Pensa-se que o labor de Yinka, assim como o do escritor Antonio Jacinto, verificado por Montaury, tangencia essas feridas decorrentes dos processos de tensionamento no contato entre núcleos sociais com interesses conflitantes. Por essa lente, é como se a obra ofertasse um recorte do "contínuo do real", como problematiza Vera Figueiredo em sua discussão sobre os novos realismos e ilusionismos, numa espécie de "cruzada contra o artifício da pretensa verdade da história oficial. Ao fazê-lo, a obra coloca seu leitor/espectador 'diante da brutalidade do real'” (FIGUEIREDO, 2010, p. 127, 130, 131). Algo que se aproxima ao entendimento do ato mimético explicitado por Schøllhammer (FIGUEIREDO, 2010, p. 144), que se molda na criação produtora que permite ao "leitor um conhecimento melhor de si e da inserção própria no mundo." Por certo esse é um projeto essencialmente político e, ao mesmo tempo, estético. Tal assertiva é referendada por Shonibare, em trecho da entrevista concedida a Okwui Enwezar, no excerto adiante:

[...] e eu não desvinculo a estética da política - a estética atualmente é uma expressão da política, certo? Você pode fazer política formalmente. Isto é um jeito simples de colocar a questão; a forma que eu faço isto, é mais um tipo de alerta, à moda carnavalesca, na qual eu coloco minha língua para fora. Nenhum grupo detêm o monopólio em estética. (ENWEZAR, 2003, p. 165). 


\section{CESPUC}

Resta voltar o foco na tentativa de perceber como se materializa essa vertente neorealista na instalação de 2009, vista na Figura 1, denominada Party time: re-imagine America.

Figura 1 - Diferentes tomadas da Instalação Party time: re-imagine America (2009)
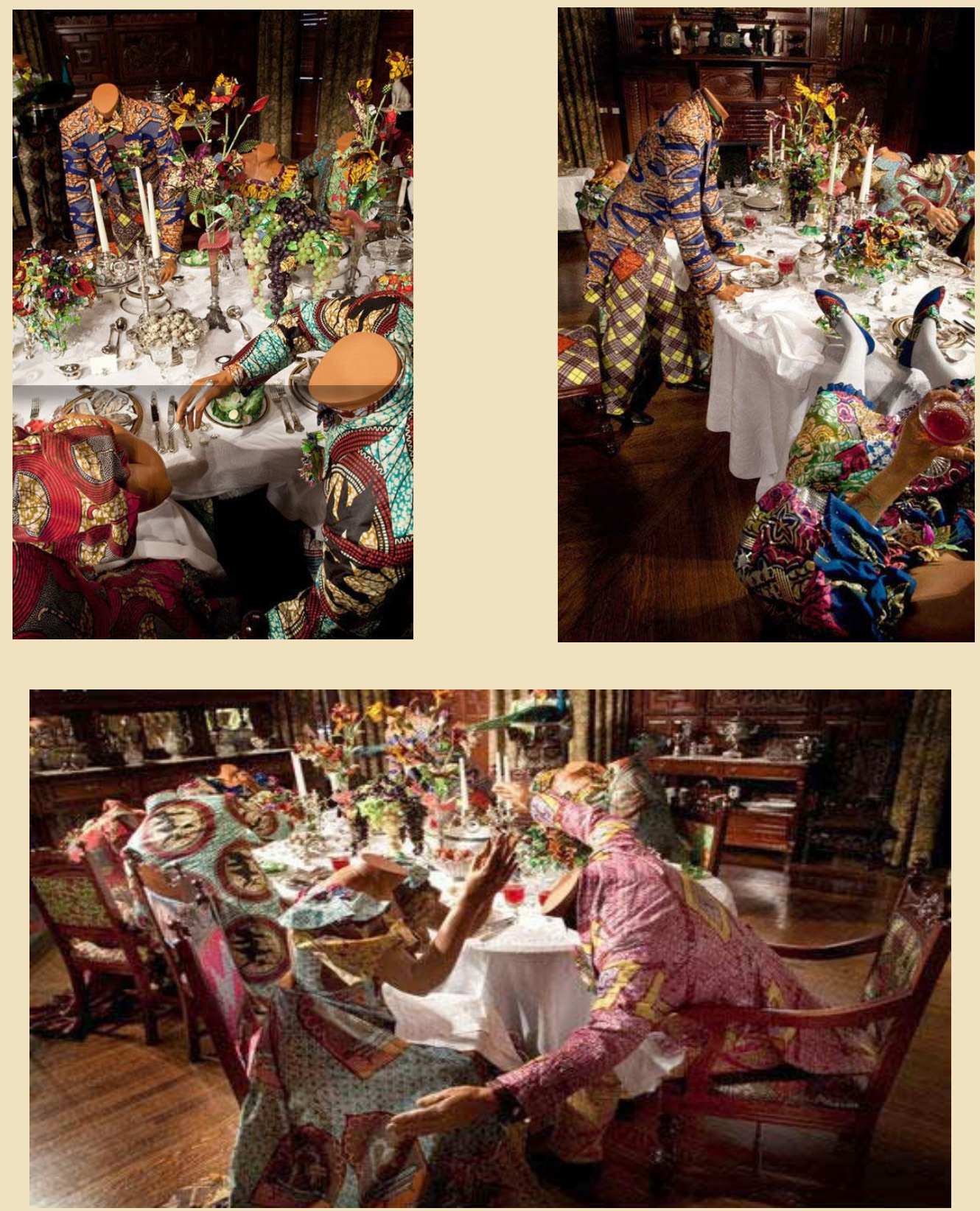

Fonte: YINKA, 2013. 


\section{CESPUC}

estilo vitoriano do século XIX, com o tecido característico da palheta de Shonibare, assentados ao redor de uma extravagante mesa de jantar. A mesa e a montagem dos aparatos são parte de um conjunto e apropriados para o período vitoriano. Os restos de ostras e ovos de codornizes estão espalhados na superfície da mesa, enquanto um criado aparece trazendo o prato principal: um pavão (um símbolo de luxúria) numa bandeja de prata. As posturas animadas dos convivas sugerem uma embriagante celebração. O subtexto da instalação de Shonibare é a disparidade de riqueza gerada pela industrialização no final do séc. XIX. A complacência de uns poucos privilegiados tornou possível a exploração de outros, frequentemente envolvendo o trabalho barato de imigrantes, na época atual.

A Ballantine House oferece um aproveitamento extraordinário para a instalação. Em tempos históricos, os Ballantines foram imigrantes escoceses que fizeram riqueza no ramo da fabricação de cerveja; sua casa é o símbolo perfeito da divisão social e econômica da Idade de Ouro americana (GENOCCHIO, 2009). Há também um tom bem humorado na instalação, notadamente em detalhes como a figura feminina que entorna sua taça de vinho enquanto tomba para trás, aparentando querer fujir às apalpadelas e sendo socorrida por um conviva. Outra mulher tem seus pés sobre a mesa, braços esparramados, numa flagrante contravenção à etiqueta social.

Com o mesmo mote do conto de Luandino, que encena a realização de um estupendo banquete, também presente em Party time, na escultura a seguir (FIG. 2), Last supper (after Leonardo), o elemento a congregar as pessoas é a soberba mesa já posta.

Figura 2 - Diferentes tomadas da Escultura Last supper (after Leonardo) (2013)

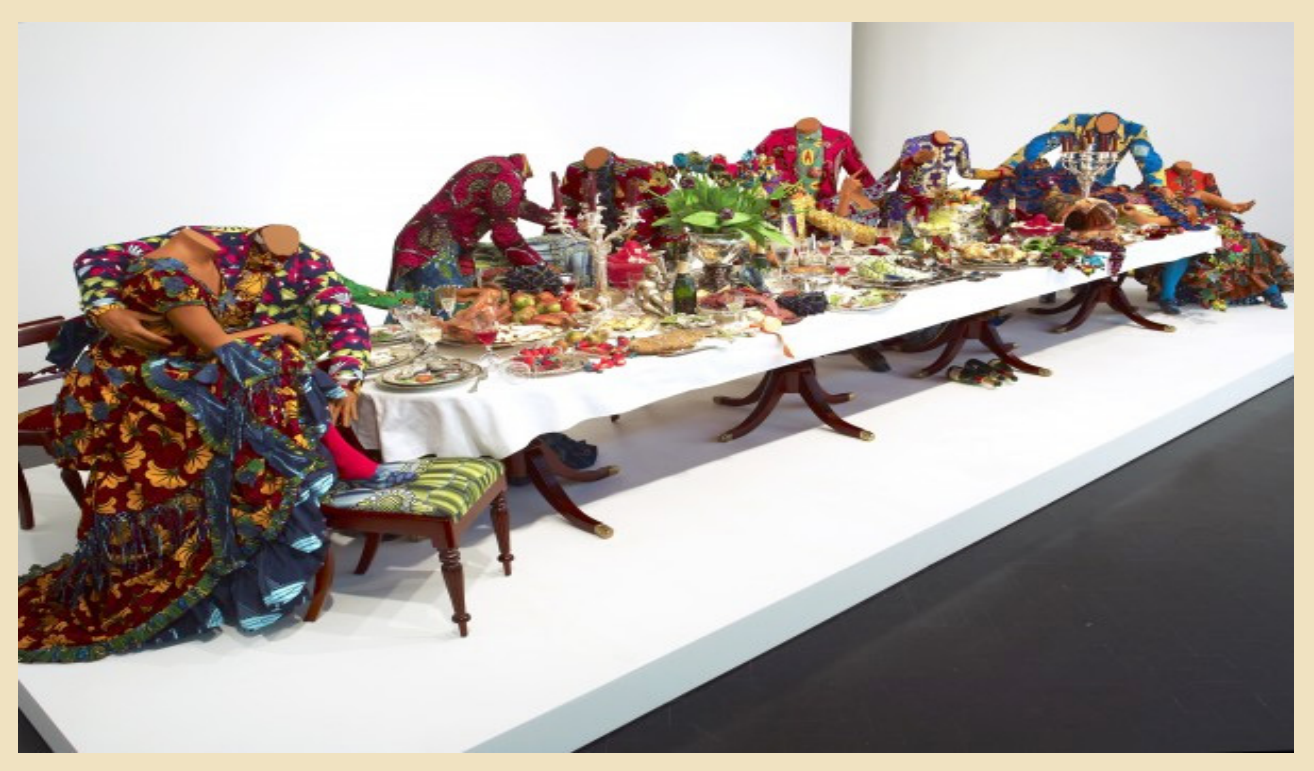




\section{CESPUC \\ 1 O SEMESTRE DE $2018-$ N. 32}
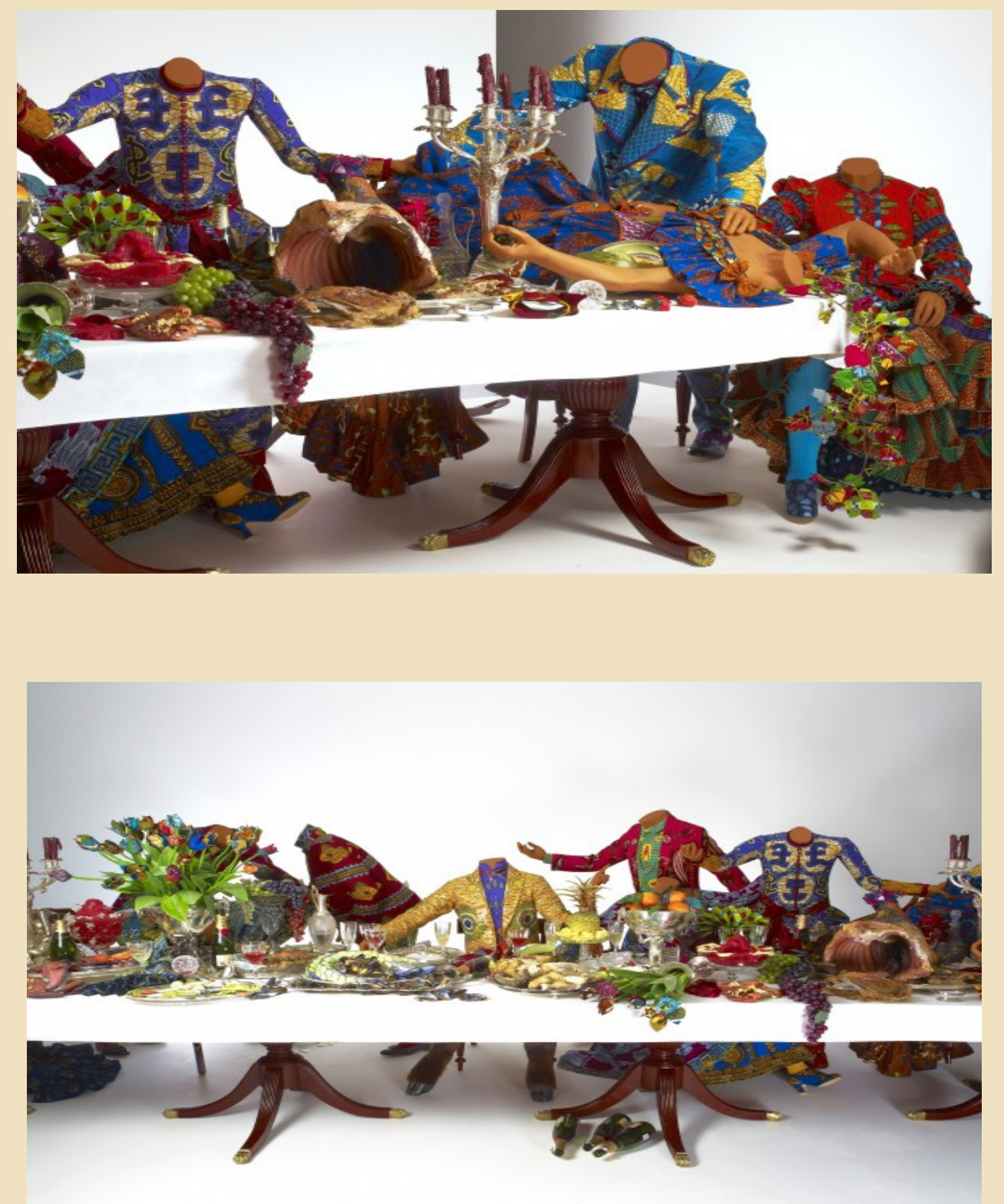

Fonte: YINKA, 2013.

Last supper apresenta treze manequins degolados vestidos com a estamparia batique, incluindo uma figura híbrida com patas de animal revestidas de pele e lustrosos cascos pretos; uma enorme mesa e seu conjunto de cadeiras de madeira; vasos e cutelaria de prata, reproduções antigas de taças e baixelas em fibra de vidro e resina.

Nessa bizarra e, ao mesmo tempo, fenomenal "última ceia”, retomada da bela cena fulcral do cristianismo, presentificam-se todos os elementos do trabalho engajado com a visão ideológica de arte praticada por Shonibare. Não há espaço para a inocência do espectador/leitor diante da alusão direta registrada já no nome da escultura, uma retomada com outras possibilidades de significação, da célebre pintura de Leonardo da Vinci, concebida entre 1495-1497. 
Há margem para a leitura de um Judas reestilizado, de casaco azul com estampas das cifras do dólar americano e das libras esterlinas, à esquerda do que parece remeter a Jesus. Há forte ironia na presença da mulher, escanchada por sobre a mesa e tendo os seios apalpados escancaradamente por um dos convivas e, também, a perna tocada pelo "Judas". Uma ceia vista como um bacanal intensificado, na outra cabeceira da mesa, pelo atracar de um casal e, ademais, pela pose da mulher com o pé por cima da cadeira e, para além disso, da outra mulher deitada sobre a mesa e com um dos seios segurado pela mão de uma figura masculina. Causa maior perplexidade justamente o ser híbrido, que, por ocupar o lugar central da mesa, remete inevitavelmente a Jesus Cristo, da tela de Da Vinci. Nesse construto esteticamente politizado de Shonibare parece latente o convite a que se rompa a já aludida "anestesia cultural", nos termos em que é colocada por Schøllhammer (2012, p. 136).

\section{Palavras finais}

O que não existe continua a insistir, lutando para passar a existir.

(ZIZEK, 2003, p. 37)

O presente ensaio almejava refletir sobre as facetas que o novo realismo assumia no construto literário de Luandino Vieira e na criação artística de Yinka Shonibare, MBE. O viés analítico empreendido permitiu a confirmação da hipótese levantada, pois o mergulho nesse corpus evidenciou as estratégias desses dois africanos de tomar como ingrediente de criação as várias mesclagens de tradições e configurações espaço-temporais que contribuem, inclusive, para desmascarar a falácia acerca da autenticidade étnica.

De acordo com o professor de arte e estudos transculturais Jean Fisher (2008, p. 210), "como demonstram as poéticas diaspóricas - contrariando as reivindicações do modernismo - a arte nunca cessa de projetar o passado no futuro; ela interpreta a história para desencobrir as mais profundas 'verdades' da nossa situação histórica mundial”. Vale retomar Zizek, quando atesta que

o núcleo da 'paixão pelo Real' é essa identificação com [...] a obscenidade suja do outro lado do Poder: a atitude heróica de que 'alguém tem de fazer o trabalho sujo, então, mãos à obra!' [...] heróis prontos a fazer o trabalho sujo necessário: é fácil fazer uma coisa nobre pela pátria, até sacrificar a própria vida por ela - é muito mais difícil cometer um crime pela pátria... (ZIZEK, 2003, p. 45).

Por fim, como bem salienta o filósofo Zizek, nga Tonha, bem como, os manequins degolados são arautos empenhados, insistentemente, em tomar como repertório, como matéria estéticopolítica, justamente as "obscenidades" da arena de que fazem parte sociedades mescladas, de interesses conflitantes. Luandino Vieira e Yinka Shonibare, MBE felizmente se prestaram a fazer, e muito bem, o trabalho sujo primordial para deslindar e intervir no agenciamento de experiências da realidade advindas de intensos processos de misturas. 


\section{REFERÊNCIAS}

BARAN, Jessica. Featured review: Yinka Shonibare: Mother and father worked hard so I can play. St. Louis Arts, 18 Jan. 2010.

CAMPBELL-JOHNSTON, Rachel. Dandy in the undergrowth. The Time, 28 Nov. 2006.

CANDIDO, Antonio. Realidade e realismo (via Marcel Proust). In: CANDINO, Antonio. Recortes. São Paulo: Companhia das Letras, 1993. Cap. 22, p. 123-129.

CARVALHO, Wellington Marçal de. Anatomia de um relógio. 2011. Disponível em: < http:// www.pucminas.br/documentos/cadern_resumos.pdf?PHPSESSID=c8dd882e2615b09fbaab 4eafd8ca1954>. Acesso em: 29 jun. 2013.

COOKE, Rachel. Yinka Shonibare's Nelson's ship in a bottle will take its place on Trafalgar Square's fourth plinth later this month. The Observer, 2010.

DINIZ, Thais Flores Nogueira. Nova luz sobre Heart of darkness: "The scramble for Africa”, de Yinka Shonibare. Revista Letras \& Letras, Uberlândia, v. 27, n. 2, p. 359-372, jul./dez. 2011.

ENWEZAR, Okwui. Yinka Shonibare: of hedonism, masquerade, carnivalesque and power. Looking both ways: art of contemporany African diaspora, 2003. p. 162-177.

FIGUEIREDO, Vera Lúcia Follain de. Novos realismos, novos ilusionismos. In: FIGUEIREDO, Vera Lúcia Follain de. Narrativas migrantes: literatura, roteiro e cinema. Rio de Janeiro: PUCRio, 2010. p. 119-132.

FISHER, Jean. Diaspora, trauma and the poetics of remembrance. In: MERCER, Kobena. (Ed.). Exiles, diasporas \& strangers: annotating art's histories. London: INIVA / The MIT Press, 2008. p. 190-212.

FONSECA, Maria Nazareth Soares. Literatura e oralidade africanas: mediações. Mulemba, Rio de Janeiro, v. 14, n. 2, p. 12-34, jul./dez. 2016.

GENOCCHIO, Benjamin. The rich were different (and perhaps still are). The New York Times, 10 Jul. 2009.

GIULIANO, Charles. Dressed for success: not necessarily out of Africa. NYArts Magazine, 2004.

KHOSA, Ungulani Ba Ka. Ualalapi. Belo Horizonte: Nandyala, 2013. 125 p.

LABAN, Michel. (Org.). Luandino: José Luandino Vieira e a sua obra (estudos, testemunhos, entrevistas). Lisboa: Edições 70, 1980. 323 p.

MILLIARD, Coline. Yinka Shonibare MBE: same but different. Catalogue Issue 1. September. 2009. 


\section{（ESPUC \\ 1 O SEMESTRE DE $2018-$ N. 32}

MONTAURY, Alexandre. Criar e ativar novas realidades: Antônio Jacinto e o testemunho da exclusão. In: MONTAURY, Alexandre; MARGATO, Izabel; GOMES, Renato Cordeiro (Org.). Novos realismos. Belo Horizonte: UFMG, 2012. p. 103-117.

OLOWU, Duro. Appraises the Brooklyn Museum's Yinka Shonibare exhibition. Vogue, Jul. 2009.

SCHØLLHAMMER, Karl Erik. Realismo afetivo: evocar realismo além da representação.

Estudos de Literatura Brasileira Contemporânea, n. 39, jan./jun., p. 129-148, 2012.

SONTAG, Deborah. Headless bodies from a bottomless imagination. The New York Times, 17 Jun. 2009.

VIEIRA, José Luandino. A cidade e a infância. São Paulo: Companhia das Letras, 2007. 135 p.

VIEIRA, José Luandino. Estória de família: (Dona Antónia de Sousa Neto). In: VIEIRA, José Luandino. Lourentinho, Dona Antónia de Sousa Neto \& eu. Luanda: Maianga, 2004. p. 5598.

VIEIRA, José Luandino. João Vêncio: os seus amores. 2. ed. Lisboa: Edições 70, 1979. 113 p.

WYNDHAM, Constance. Yinka Shonibare. Art + Auction, Feb. 2008. p. 54-58.

YINKA Shonibare. [Informações]. In: Yinka Shonibare website. Disponível em: <http:// www.yinkashonibarembe.com>. Acesso em: 20 jun. 2013.

ZIZEK, Slavoj. A visão em paralaxe. São Paulo: Boitempo, 2008. 507 p.

ZIZEK, Slavoj. Paixões do real, paixões do semblante. In: ZIZEK, Slavoj. Bem-vindo ao deserto do real. São Paulo: Boitempo, 2003. Cap. 1. p. 19-47. (Estado de sítio). 